\title{
Flash-floods in Catalonia: the social perception in a context of changing vulnerability
}

\author{
M. C. Llasat ${ }^{1}$, L. López ${ }^{2}$, M. Barnolas ${ }^{1}$, and M. Llasat-Botija ${ }^{1}$ \\ ${ }^{1}$ Meteorological Hazards Analysis Team (GAMA), Department of Astronomy and Meteorology, University of Barcelona, \\ 08028 Barcelona, Spain \\ ${ }^{2}$ Laboratory for Atmospheric Physics, University of León, León, Spain
}

Received: 11 February 2008 - Revised: 20 June 2008 - Accepted: 30 June 2008 - Published: 29 July 2008

\begin{abstract}
In assessing a flood event two risk components need to be considered: the intrinsic hazard of the hydrometeorological event causing the flood and the vulnerability of the area where the precipitation has been registered. In the present study four flood events selected by the FLASH European project have been classified according to the characteristics of the meteorological event (classification according to hazard) and according to the physical and economic damages caused (classification according to vulnerability). The social impact of these events is analysed taking into account the growth of the population. An increase in the number of extraordinary flash-floods was detected in the areas with a major growth of the population, as a consequence of an increased vulnerability of these areas, both from a physical perspective (exposure of infrastructures) and from an economic perspective (more goods exposed). In addition, the numerous non-native inhabitants of the region are not aware of the meteorological risks characteristic of the area, and this contributes to increased social vulnerability.
\end{abstract}

\section{Indroduction: flood risk, vulnerability and resilience}

Water is a vital resource, but beyond the acceptable thresholds it becomes a risk. When the upper threshold is surpassed the flood risk is considered, but when values are below the lowest threshold, there is a drought risk. These thresholds are non-stationary over time. The lifestyle of developed countries is leading to a narrower rage of tolerance, and this fact, combined with an increase of the population and other factors, points towards higher vulnerability. In parallel, the last IPCC (2007) shows an increase of the extreme hazard as a consequence of climate change. If both increases in hazards

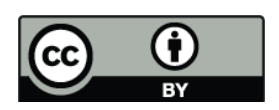

Correspondence to: M. C. Llasat (carmell@am.ub.es) and vulnerability occur at the same time, then we will be speaking about a severe increase in some natural risks.

Nowadays it seems that this increase in some natural hazards is already taking place. However, in some regions it is still too soon to determine whether this is a trend caused by climate change, whether it lies within the boundaries of natural climatic variability, or whether it is only associated with the increased vulnerability. Changes in social perception should also be added to the intrinsic difficulties in analyzing changes in hazard and vulnerability. This social perception is highly influenced by the press, which focuses mainly on the vulnerability component of risk (casualties, damages, losses) and less so on the actual hazard, and that depends on other social circumstances (Llasat et al., 2007).

In Europe, floods have been recently recognized as a major natural risk because of their frequency of occurrence and also because of the intensity of the precipitation registered. Within the boundaries of the Iberian Peninsula, Catalonia is one of the most affected areas. In fact, a total of 217 flood events were registered in Catalonia between 1901 and 2000, most of them near the coast (Barnolas and Llasat, 2007). Catalonia, and especially the coast, is particularly vulnerable to flash-floods. This vulnerability reveals itself from a physical point of view (residential areas are built on floodable land) and from a social point of view (increased population density, a growing number of foreigners who are not familiar with the risks in the area and do not know how to react, a lack of information campaigns in relation with these risks).

The aim of this paper is to clasify the main flood events recorded in Catalonia between 2005 and 2006. A classification that enables a flood event to be described according to its hazard (type of precipitation) and according to its vulnerability (type of damage) has been applied. Additionally, an analysis was made of the extent to which higher population density has increased the vulnerability in certain coastal areas of Catalonia.

Published by Copernicus Publications on behalf of the European Geosciences Union. 
Table 1. Maximum rainfall values recorded in $24 \mathrm{~h}$ and maximum rainfall values registered in the first three days of the event.

\begin{tabular}{lllll}
\hline $\begin{array}{l}\text { Case } \\
\text { studies }\end{array}$ & $\begin{array}{l}\text { Max. Accum. } \\
24 \mathrm{~h}\end{array}$ & $\begin{array}{l}\text { Max. Accum. } \\
\text { period }\end{array}$ & $\begin{array}{l}\text { Total } \\
\text { time }\end{array}$ & $\begin{array}{l}\text { Type of } \\
\text { flood }\end{array}$ \\
\hline $2 / 8 / 05$ & 57.1 & 57.1 & $24 \mathrm{~h}$ & 1 \\
$11-13 / 10 / 05$ & 254.4 & 348.2 & $72 \mathrm{~h}$ & $2 \mathrm{~b}$ \\
$13-15 / 11 / 2005$ & 120 & 148.1 & $72 \mathrm{~h}$ & $2 \mathrm{~b}$ \\
$12-14 / 09 / 2006$ & 216 & 266.1 & $72 \mathrm{~h}$ & $2 \mathrm{~b}$ \\
\hline
\end{tabular}

\section{Floods and flash floods in Catalonia in the 21st cen- tury}

Catalonia is a region located in the NE of the Iberian Peninsula (Fig. 1), with an area of about $31930 \mathrm{~km}^{2}$. The region is surrounded by the Mediterranean Sea to the East, the Pyrenees to the North and the Valley of the River Ebro to the West. With respect to the topography of the area, in the North the average altitude of the Pyrenees is $3000 \mathrm{~m}$, and there are two different mountain ranges running parallel to the coast: the littoral range with an altitude of $1700 \mathrm{~m}$, and the prelittoral range with an average altitude of $700 \mathrm{~m}$. Bearing in mind these topographic features, three types of rivers may be distinguished:

a. High-mountain-rivers of pluvial snowmelt origin with large basins $\left(>2000 \mathrm{~km}^{2}\right)$ and perennial flows.

b. Rivers of pre-littoral rainfall origin with modest basins $\left(50-2000 \mathrm{~km}^{2}\right)$ and flows. Some of them have ephemeral streams.

c. Short littoral water courses with considerable slope and characterized by torrential regimes and non-permanent flows and small basins $\left(5-50 \mathrm{~km}^{2}\right)$.

\subsection{Types of floods and historical flood classification}

Taking into account the topography and the types of rivers described above, and considering the meteorological characteristics of the precipitation event, a typology of floods in Catalonia has been set up according to their hazard and potential impact (Llasat, 2008). Convective features of the rainfall field at surface have also been taken into account by using the $\beta$ parameter, defined as the ratio between convective precipitation and total precipitation (Llasat, 2001; Llasat et al., 2007). The type of precipitation structures is also considered in the classification (Rigo and Llasat, 2004; Doswell et al., 1996)

- Type 1: Short-lived events of very intense precipitation but for which the total amount of rainfall is not usually very high. They are strongly convective events caused

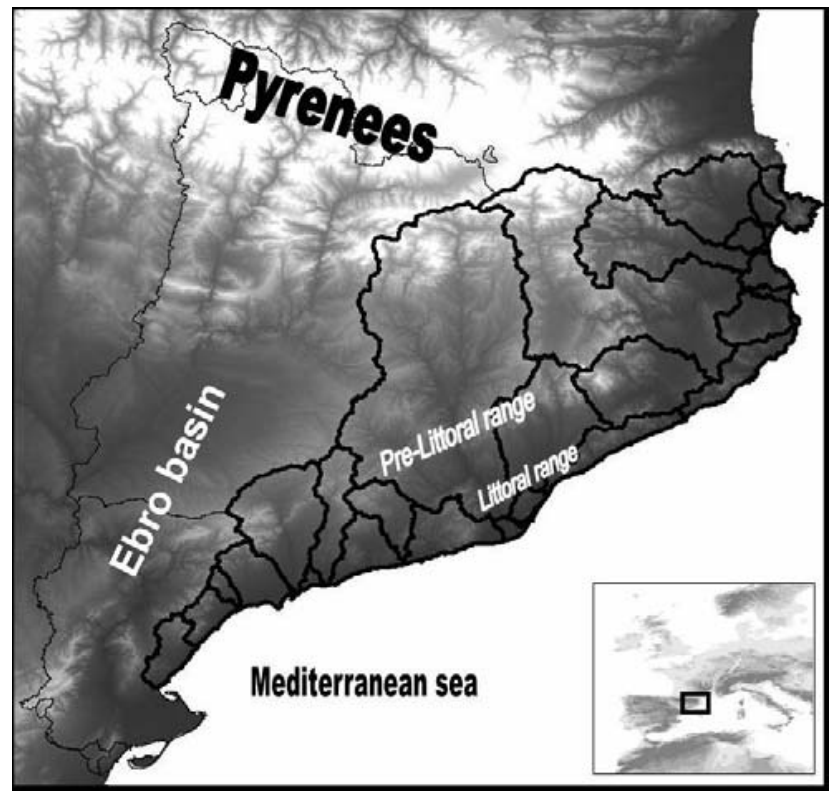

Fig. 1. Map of Catalonia. Black lines represent the Internal Basins of Catalonia, the zone affected by the case studies analyzed here.

by isolated cells or multicells with a limited horizontal extension. They appear during summer and early autumn and produce local flash-floods in rivers of type c. They affect mainly the narrow river beds near the coast in densely inhabited and tourist regions, causing minor damage but sweeping away cars parked in the water courses or in adjoining streets. Casualties are usually the result of the unwise behaviour of people.

- Type 2: Episodes of heavy rain sustained for several hours, which may lead to catastrophic floods due to the daily rainfall amount or widespread extension. Convective rainfall is generally caused by multicells or mesoscale convective systems. These events usually occur in autumn, although some cases have also been recorded in spring or summer. It is possible to distinguish between two subclasses. Type 2a lasts less than $24 \mathrm{~h}$ and the maximum precipitation is usually registered in less than $6 \mathrm{~h}$. They are strongly convective events and may cause catastrophic flash floods in rivers of type b and c. When they affect flood-prone areas with high concentrations of people, they may cause the highest number of casualties. Type $2 \mathrm{~b}$ lasts more than $24 \mathrm{~h}$ but generally less than four days. Peaks of strong rainfall intensity and moderate but continuous rainfall are recorded successively. Consequently, they are moderate convective events, and while they can also produce local flash floods in rivers of type $\mathrm{c}$, the floods occurring in rivers of type $b$ and, sometimes in type $a$, are the most significant. Damages caused by catastrophic floods of this second type include total or partial destruction of 

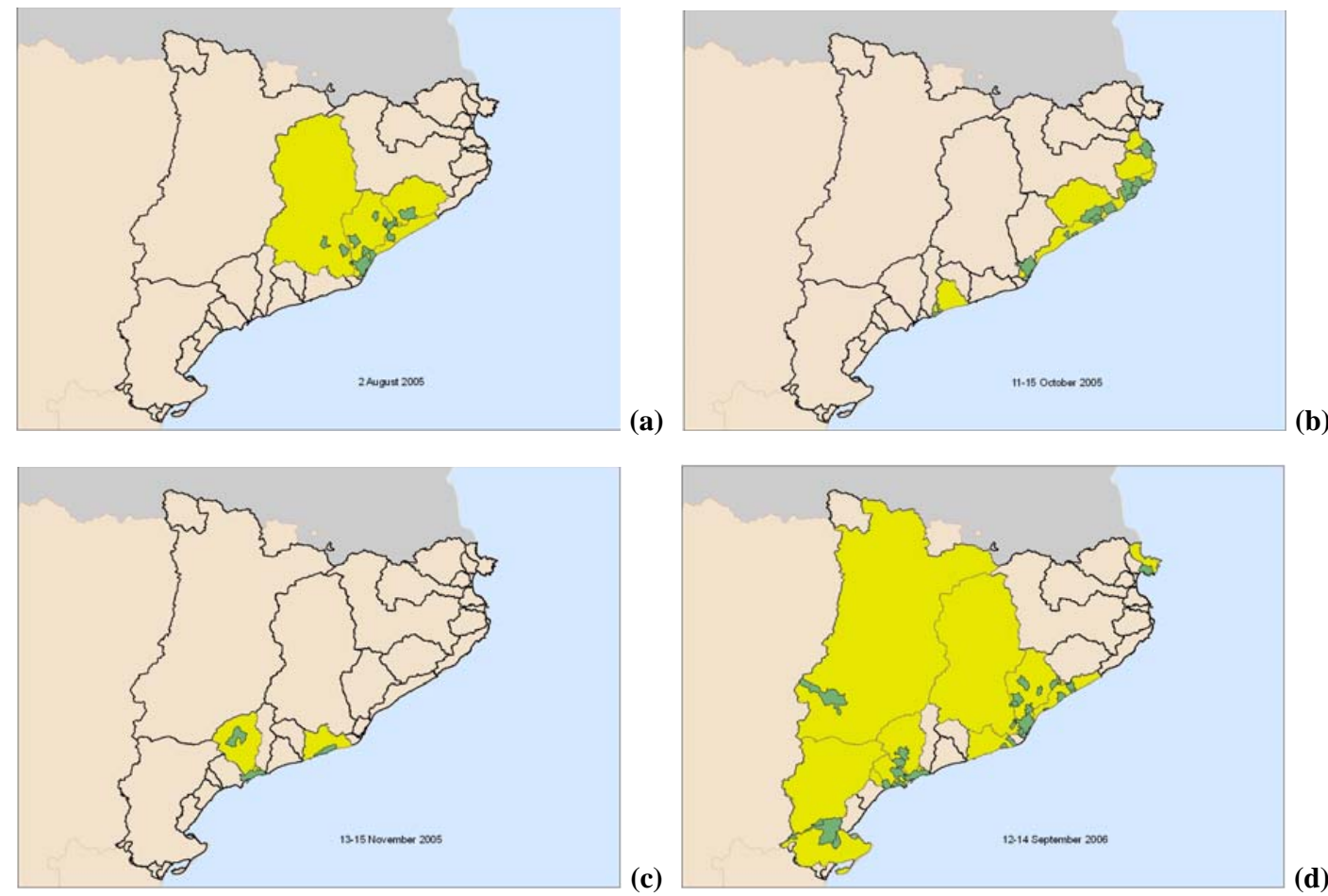

(b)

Fig. 2. Map of Catalonia showing the catchments (yellow) and municipalities (green) affected by the flash-flood events selected into the FLASH project. (a) 2 August 2005; (b) 11-15 October 2005; (c) 13-15 November 2005; (d) 12-14 September 2006.

infrastructures, power cuts, urban floods, agricultural and livestock losses and, frequently, human casualties.

- Type 3: Episodes of long duration with weak average pluviometric values, while there may be peaks of high intensity. Total precipitation can be over $200 \mathrm{~mm}$. If floods occur, they are usually in rivers of type a and b. They are "slightly convective events", usually associated with convection embedded in stratiform rainfall. Although not very frequent, they usually occur in winter and, sometimes, in spring.

This classification cannot be applied to historical floods for which the only information available relates to social impact and some scant data about the evolution of the event. In this case the classification has been established according to damage, and three types of floods have been distinguished (Llasat et al., 2003b):

_ "Ordinary floods" are those that cause hardly any damage.

- "Extraordinary floods" are those that cause minor or partial damage to infrastructures or the partial destruction of the infrastructures built over rivers, such as wooden bridges, footbridges, etc.

- "Catastrophic floods" cause the total destruction of infrastructures (bridges, houses, factories, etc.) and significant material damage.
This last scale can be also applied to recent events, in order to build up a common series starting some centuries ago and ending nowadays (Barrera et al., 2006)

\subsection{The selected FLASH events}

The most important catastrophic flood recorded in Catalonia in the 21th century occurred on 10 June 2000, with $215 \mathrm{~mm}$ of rain registered in three hours, economic losses of over $€ 65$ million and five casualties. It was an event of type $2 \mathrm{a}$. This event, known as the "Montserrat" event, had a major societal impact, and it has been studied in detail as an example of Mediterranean flash floods by many national and international projects (Llasat et al., 2003a; Mariani et al., 2005; Milelli et al., 2005).

However, the Montserrat flood has not been the last flash flood to affect Catalonia. Since June 2000, eleven extraordinary floods or flash-flood events have affected this region. Four of these cases have been selected by the European Project FLASH as case studies 2 August 2005, 11-15 October 2005, 13-15 November 2005 and 12-14 September 2006. All these events caused flash-floods over the coastal region, as shown in Fig. 2. Table 1 shows the accumulated precipitation for different time intervals and events.

On 2 August 2005 an extraordinary flash flood of type 1 affected the Besós, Tordera and Barcelona catchments (Fig. 2a), while hail was recorded in several parts of Catalonia. It was a strongly convective event, with a 


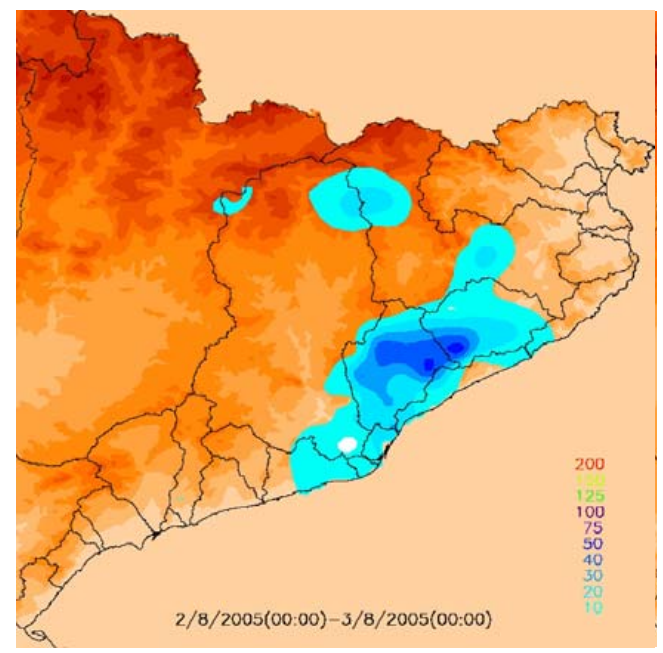

(a)

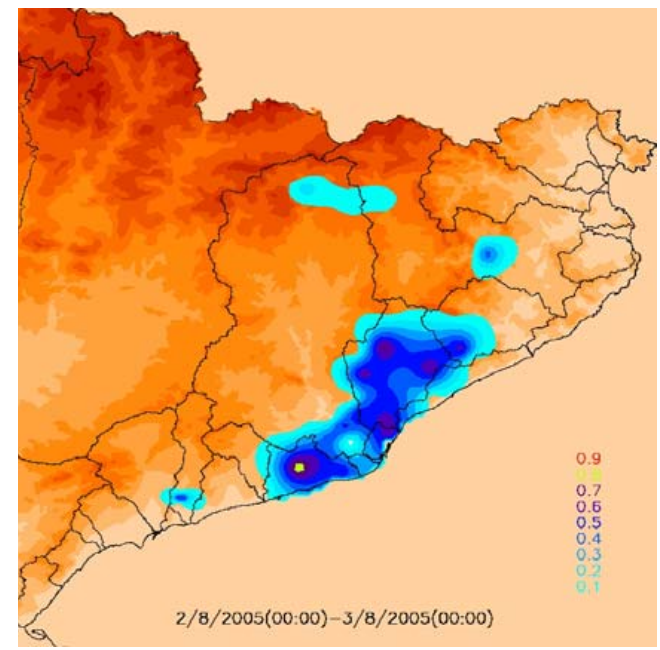

(b)

Fig. 3. (a) Rainfall field between 2 August 2005 at 00:00 UTC and 3 August 2005 at 00:00 UTC; (b) $\beta$ field for the same time interval.

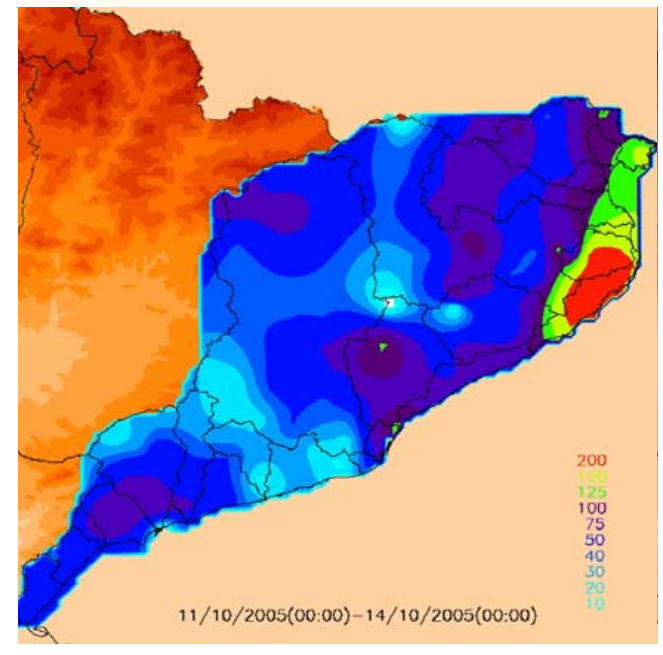

(a)

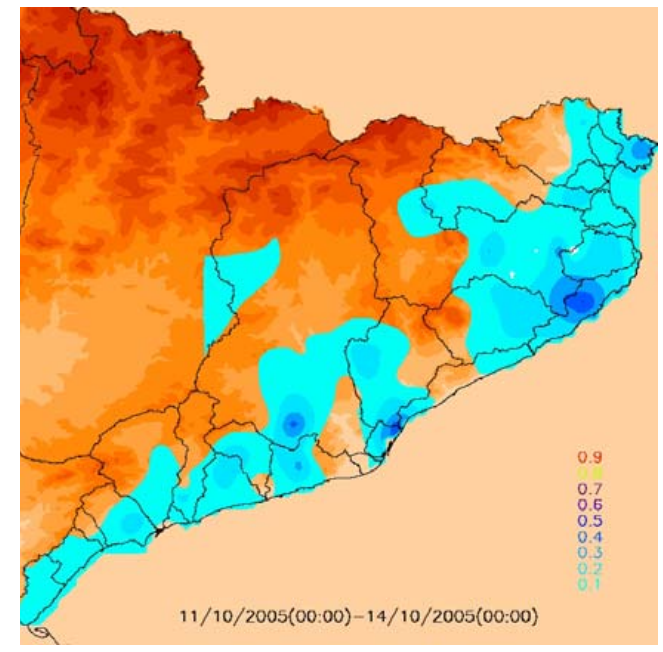

(b)

Fig. 4. (a) Rainfall field between 11 October 2005 at 00:00 UTC and 14 October 2005 at 00:00 UTC; (b) $\beta$ field for the same time interval.

maximum of $56 \mathrm{~mm}$ in $1 \mathrm{~h}$ and $571 \mathrm{~mm}$ in $24 \mathrm{~h}$ (Fig. 3a). In some regions more than $80 \%$ of the precipitation was convective (Fig. 3b). One man died because he was swept away by the current while he was driving his tractor. There were damages in crops, road cuts, railway cuts and power cuts.

Between 11 October 2005 and 15 October 2005 several catastrophic floods of type $2 b$, as well as landslides, affected the Central and Northern coast (Fig. 2b). Flash-floods occurred on 13th October in the Maresme as well as in the rivers Riadura, Daró and Calonge. There were four deaths: one woman carried away by the stream flow, and three when they tried to cross the "Riera" in their car. Two bridges were destroyed, $80 \%$ of the harvest in the Alt Empordà region was lost, and damage to ground floors, cellars, cars, roads, underground and railways also occurred. The damages in the Costa Brava lay over $€ 12.5$ million and 6044 claims were filed with the Consorcio de Compensación de Seguros (CCS), the national insurance company. A total of $393.4 \mathrm{~mm}$ was registered in 5 days, of which $254 \mathrm{~mm}$ were registered on 13th October alone (Fig. 4a). Although it can be considered as a moderate convective event with values of $\beta$ under $60 \%$ (Fig. 4b), the precipitation on 13th October was highly convective.

One month later, between 13 and 15 November 2005 an extraordinary flood event of type $2 b$ affected the South of Catalonia (Fig. 2c). In addition to the rainfalls, waterspouts, landslides, snowfall, hail and windstorms were also recorded. The succession of different thunderstorms gave rise to more than 4000 lightning flashes over the region in $24 \mathrm{~h}$. The balance was of one death and one person injured by a landslide in tunnel works, the Roman Wall of Tarragona was damaged and in the city of Barcelona the losses lay 


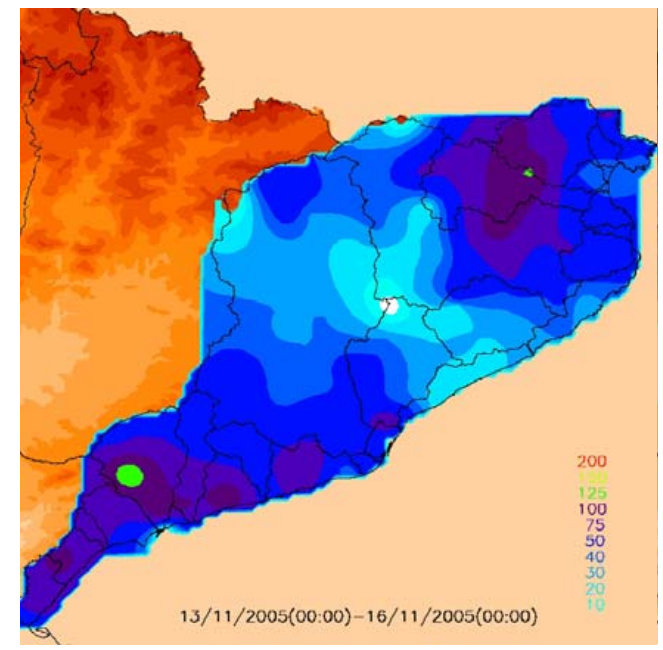

(a)

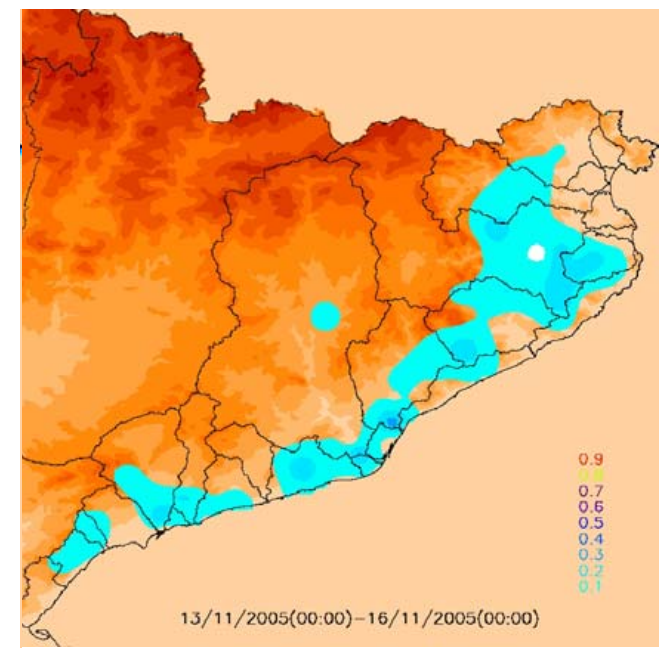

(b)

Fig. 5. (a) Rainfall field between 13 November 2005 at 00:00 UTC and 16 November 2005 at 00:00 UTC; (b) $\beta$ field for the same time interval.
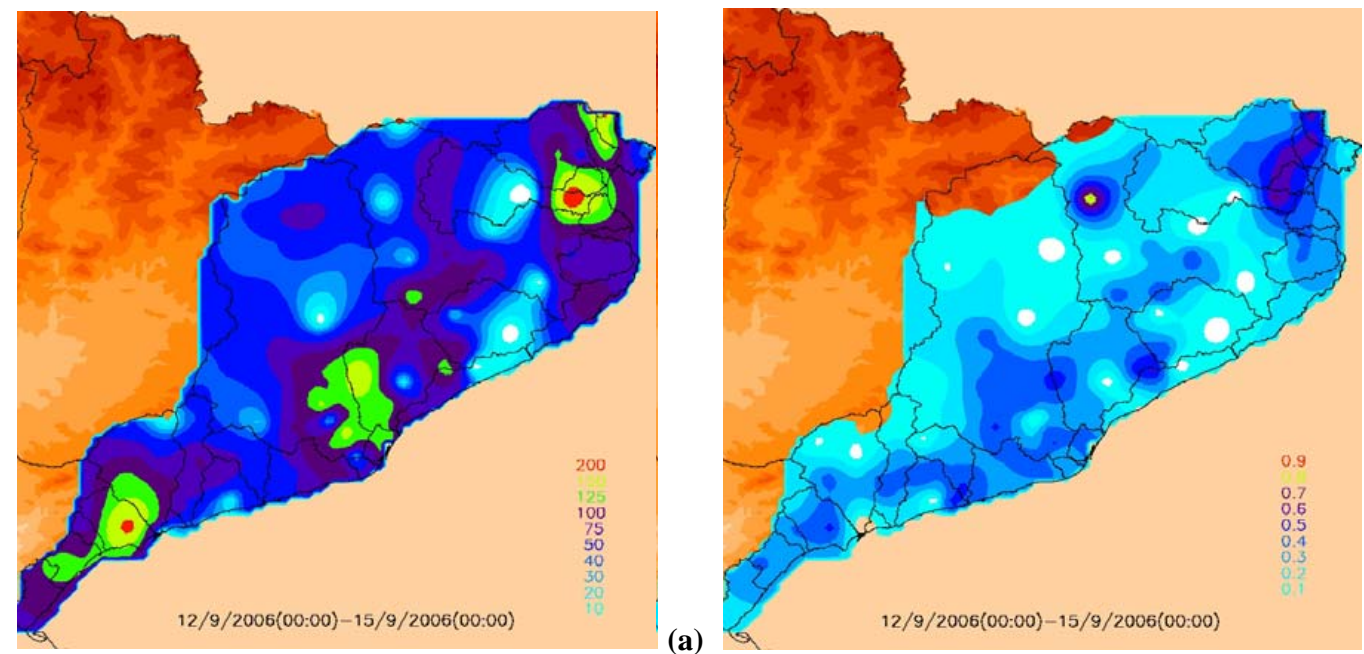

(b)

Fig. 6. (a) Rainfall field between 12 September 2006 at 00:00 UTC and 15 September 2006 at 00:00 UTC; (b) $\beta$ field for the same time interval.

over $€ 1.5$ million. A maximum accumulated precipitation of $212 \mathrm{~mm}$ was recorded over the small catchments of the rivers Foix and Riera de la Bisbal (where flash floods occurred), with $102 \mathrm{~mm}$ recorded on 13th November (Fig. 5a). As in the previous case, it was a moderate convective event (Fig. 5b).

The last case, which affected the whole of Catalonia, was characterized by flash-floods, tornadoes, lightning and landslides (Fig. 2d). Between 12 and 14 September 2006 several extraordinary flash floods were recorded as a consequence of rainfalls of between 100 and $250 \mathrm{~mm}$ in $24 \mathrm{~h}$. The event was of type $2 b$, with maximum accumulated rainfall of $267 \mathrm{~mm}$ in the South of Catalonia, and $256 \mathrm{~mm}$ in the North (Fig. 6a). Figure $6 \mathrm{~b}$ shows that it was a moderately convective event with the exception of the northern part, where $\beta$ values ex- ceeded $70 \%$. One person died while he was sleeping in a park. This event had a very high social impact. Besides damages in agriculture and in urban areas, a traffic jam brought Barcelona to a standstill, 40000 people were affected by railway cuts, the airport of Reus was closed and long delays were registered at the airport in Barcelona. Ninety cars were dragged away in Salou, and part of the chemical park in Tarragona was flooded. As a consequence, the emergency Plans of INUNCAT, PLASEQTA and CAMCAT were activated. The CCS insurance company paid out $€ 55993194$ million for damages caused by floods and landslides, and $€ 3.15$ million for damages caused by tornadoes.

In total, the four cases caused damages of $€ 73 \mathrm{M}$ and 7 deaths. Although the meteorological events lasted more than one day, and $75 \%$ of the cases could be considered as type $2 \mathrm{~b}$, 


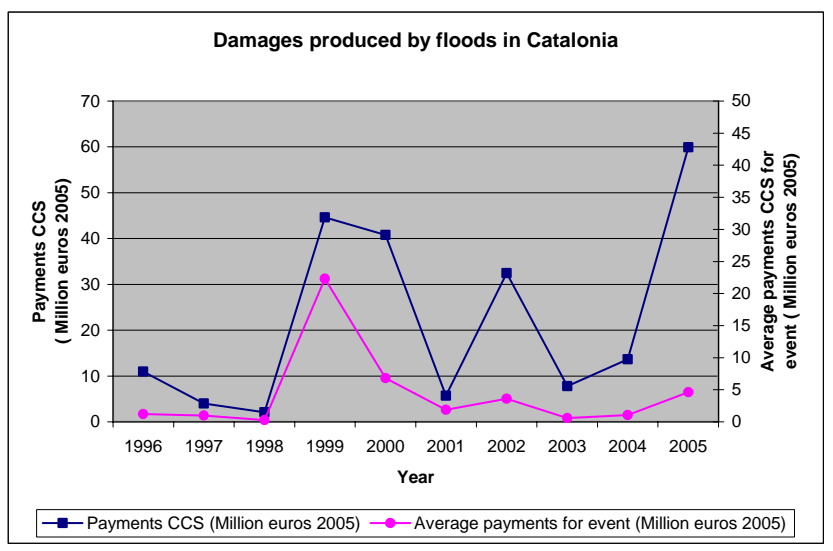

Fig. 7. Evolution of the payments made by the Consorcio de Compensación de Seguros for damages caused by floods, and evolution of the average payments per event (amount of money divided by the number of flood events) between 1996 and 2005.

all the cases recorded flash floods in small catchments near the coast, the most densely inhabited part of Catalonia. This fact will be decisive in the increased number of flash floods detected when the criteria used are correlated with damage.

\section{Evolution of vulnerability and social impact}

\subsection{Damage evolution}

Eleven extraordinary or catastrophic flood events were recorded between the years 2000 and 2006. The damages caused by this type of event have increased considerably in Catalonia. The damages associated with the Montserrat event amounted to $€ 65 \mathrm{M}$, while the damage compensation paid out by the CCS due to floods in 2005 was $€ 59892409 \mathrm{M}$, and between July and October 2006 more than $€ 80 \mathrm{M}$ was paid in compensation payments for the event described above and other less intense events. The total amount paid out in compensation for damages caused by this type of phenomena between June 2000 and December 2006 was more than $€ 155$ M. By comparison, between 1982 and 1989 six catastrophic floods were recorded in Catalonia, with the flood event of November 1982 being the most catastrophic one in the Pyrenees region (France and Spain) in the last 60 years. For this last event, the CCS paid out $€ 15899787 \mathrm{M}$. It must be pointed out here that the data employed in this study were provided by the insurance company (CCS), which means that the damages were certainly higher, as not all the goods were insured. Figure 7 shows the positive trend in payments made by the CCS for damages caused by floods. The evolution of the maxima for accumulated rainfall shows that there is no direct relationship between the rainfall intensity/total and the damages and casualties. This is due to the fact that in assessing the damage the intensity of the precipitation must be taken into account,

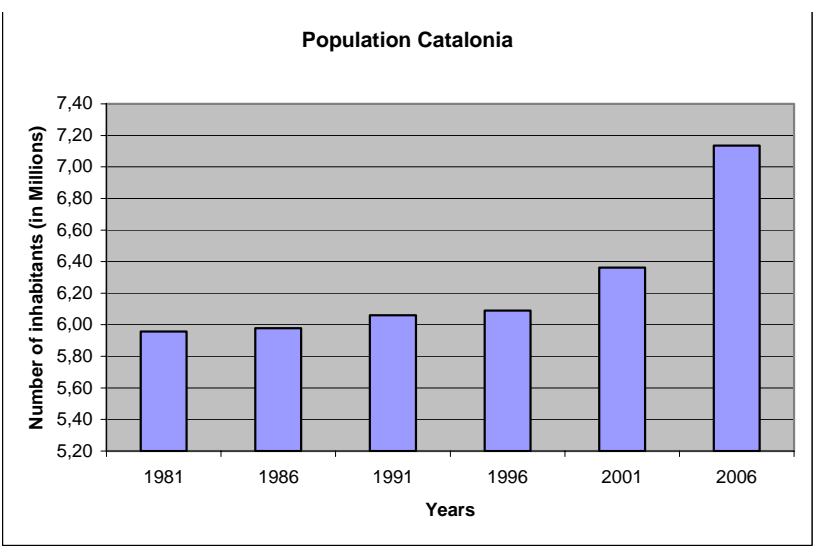

Fig. 8. Evolution of the population in Catalonia between 1981 and 2006.

but also the economic and social vulnerability of the area affected by the event. A precipitation of $224 \mathrm{~mm} / 24 \mathrm{~h}$ does not have the same effect in all regions. The damage depends on the vulnerability of the area, and one of the most important factors to consider here is the occupation of the floodprone areas. In this sense, besides the increasing population in flood-prone areas, a factor to be considered is the behavior of the population when faced with flash floods. A total of nine casualties due to flash-floods in Catalonia were reported between 2005 and 2006, 66\% of which occurred when people tried to cross a stream when the water rose. Most of the victims were foreigners. This fact points to a major need for improving information on hydrometeorological risks that can affect the region, and promoting positive attitudes among the population.

Figure 7 represents also the evolution of the average payments per event (amount of money divided by the number of floods events). For example, in 1999 there were only two flood events, but both were classified as extraordinary, so the ratio damages/flood event is very high. In 2002, another year with high losses, there were 9 flood events, 4 of which were classified as extraordinary. Finally, in 2005 there were 13 events, 4 of which extraordinary and one, the event on 11 October, caused catastrophic damages. This fact is interesting because it has revealed that in further studies it would be advisable to carry out these calculations not considering the total number of flood events, but rather more detailed facts, e.g., establishing economic thresholds or thresholds of precipitation intensity. The type of flood (ordinary, extraordinary or catastrophic following the historical criteria) to compute the mean values will not provide accurate results, since this classification considers damages to infrastructures only, and not all economic losses. A new and more updated classification should therefore be set up taking into account economic data and casualties. 


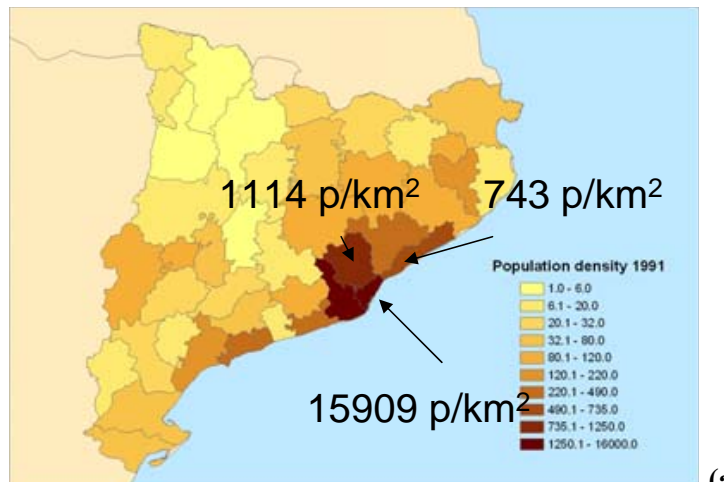

(a)

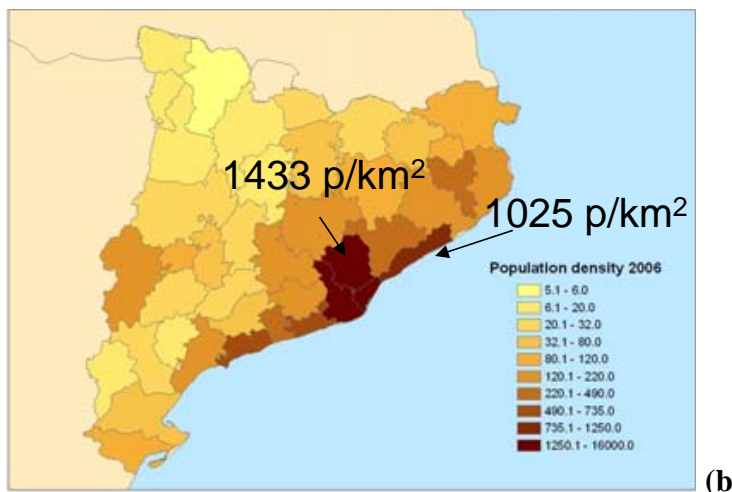

(b)

Fig. 9. Population density in Catalonia (people $/ \mathrm{km}^{2}$ ) in 1991 (a) and 2006 (b).

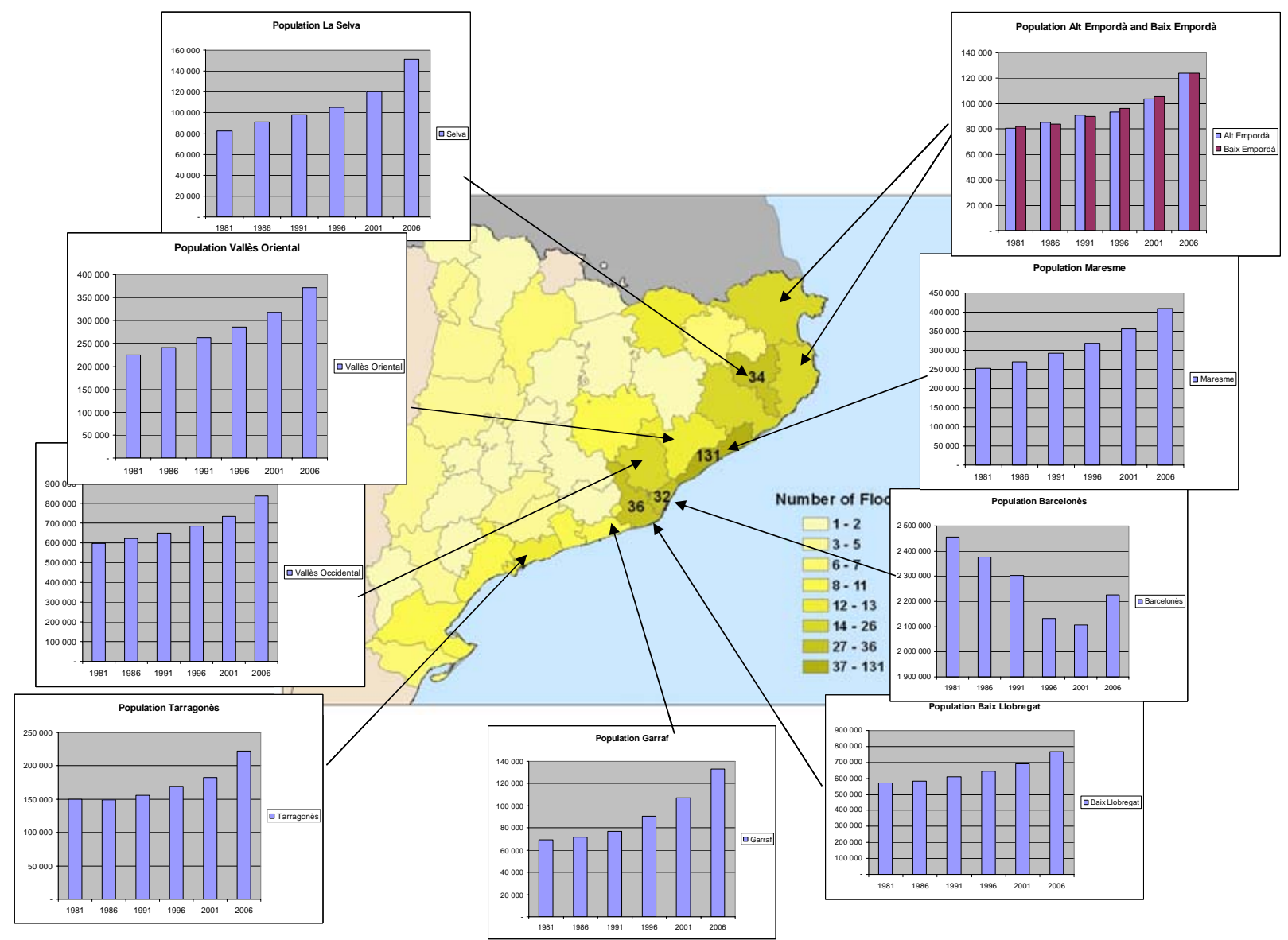

Fig. 10. Evolution of the population between 1981 and 2006 for different Catalan regions. The map shows the total number of floods recorded between 1901 and 2000; the numbers in the map refer to the floods recorded in the most flood-prone areas in the same period.

\subsection{Floods and population density}

The analysis of the evolution of the floods registered in Catalonia in the past six centuries does not show any significant trend with respect to catastrophic floods, but a slight increase in extraordinary floods (Llasat et al., 2003b). This increase may be attributed to higher hazard and vulnerability, but it may also be attributed to more extensive media coverage of this type of event or to a lower sensitivity threshold in the society with respect to this phenomenon. The rise in the number of extraordinary floods is particularly noticeable in the coast and began already in the 19th century. In the case of the city of Barcelona, although this increase in the number of extraordinary floods is also detected, the number of catas- 
trophic floods has decreased thanks to the drainage system of the city (Barrera et al., 2006).

The evolution of annual maximum daily precipitation in Barcelona from 1854 to 2005 does not show any significant trend. The explanation must therefore be found in rising vulnerability. In fact, the population of Catalonia has raised from 5956414 inhabitants in 1981 to 7134697 inhabitants in 2006. As Fig. 8 shows, a sudden increase has occurred in the last two years, mainly due to immigration. Allied to this fact, a movement of the population towards the coast and outside the capital, Barcelona, has heterogeneously affected the evolution of population density. Figure 9 shows a clearly rising trend in the population density over the last fifteen years, which is particularly significant in coastal regions, with areas such as La Selva and the Tarragonés experiencing a rise of over $4.7 \%$. The region of Barcelona is the only one that is seeing a drop in population, which is moving to live in nearby regions that are sometimes not yet prepared to house so many people, or, in most cases, lie in the most flood-prone areas (Fig. 10). This has been the case of the four flood events analysed here. Changes in land use caused by urbanisation may increase the flood hazard, while increased exposure (goods and human lives) will increase vulnerability. Furthermore, these areas are also the ones most affected by the future rise in the sea level due to climate change.

\section{Conclusions}

An increase in the number of damage events produced by flash-floods in Catalonia has been detected. Usually they are strongly and moderate convective events that produce extraordinary floods in small rivers near the coast, like the four FLASH cases analysed here. This increase has been mainly related to the increase of vulnerability. The growth of the population (with its subsequent urban development) in the towns along the Catalan coast dramatically increases the physical vulnerability of these areas. The damage in these regions has also increased considerably due to a higher number of exposed goods (higher economic vulnerability), as indicated by the increase in the number of extraordinary floods. Because of this, for a similar hazard of rain events, the flood risk is higher due to the increased vulnerability (either physical or economic). The increase in the number of foreigners in the most densely populated areas has also resulted in increased societal vulnerability, for these new inhabitants are not acquainted with the risks of the area. This lack of information is often the cause of deaths in this type of event.

No linear relationship may be established between the precipitation registered and the damage caused without considering the vulnerability of the zone being assessed. Finally, a classification of floods adapted to the type of damage registered nowadays, including casualties and not only infrastructures, will be the focus of future studies in an attempt to improve the classification of flood events and their subsequent analysis.
Acknowledgements. This study has been supported by the $\mathrm{Eu}-$ ropean Project FLASH (FP6-2005-Global-4 (n. 036852) and the Spanish project SEVERUS (CGL2006-13372-C02-02). It has been carried out in collaboration with the WMO Project MEDEX.

Edited by: A. Mugnai

Reviewed by: one anonymous referee

\section{References}

Barnolas, M. and Llasat, M. C.: A flood geodatabase and its climatological applications: The case of Catalonia for the last century, Nat. Hazards Earth Syst. Sci., 7, 271-281, 2007, http://www.nat-hazards-earth-syst-sci.net/7/271/2007/.

Barrera, A., Llasat, M.C., and Barriendos, M.: Estimation of the extreme flash flood evolution in Barcelona County from 1351 to 2005, Nat. Hazards Earth Syst. Sci., 6, 505-518, 2006, http://www.nat-hazards-earth-syst-sci.net/6/505/2006/.

Doswell, Ch. A. III, Brooks, H. E., and Maddox, R. A.: Flash flood forecasting: an ingredients based methodology, Weather Forecast., 11, 560-581, 2006.

IPCC: Climate Change 2007, Impacts, Adaptation and Vulnerability, Cambridge Univ. Press, 986 pp., 2007.

Llasat, M. C., Rigo, T., and Barriendos, M.: The 'Montserrat-2000' flash-flood event: a comparison with the floods in the Northeastern Iberian Peninsula since the 14th Century, Int. J. Climatol., 23, 453-469, 2003a.

Llasat, M. C., Barriendos, M., Barrera, A., and Rigo, T.: Climatological analysis of flood frequency in the Ter, in: Segre and Llobregat basins from the 14th to 20th Century, edited by: Thorndycraft, V. R., Benito, G., Barriendos, M., and Llasat, M. C., Palaeofloods, Historical Data and Climatic Variability. Applications in Flood Risk Assessment, 275-280, 2003b.

Llasat, M. C.: An objective classification of rainfall events on the basis of their convective features: application to rainfall intensity in the Northeast of Spain, Int. J. Climatol., 21, 1385-1400, 2001.

Llasat, M. C.: Part 4 Natural Hazards Chapter 24: High magnitude storms and floods. The Physical Geography of the Mediterranean basin Edited by Jamie Woodward. Oxford Univ. Press, in press, 2008.

Llasat, M. C., Ceperuelo, M., and Rigo, T.: Rainfall regionalization on the basis of the precipitation convective features using a raingauge network and weather radar observations, Atmos. Res., 83 415-426, 2007.

Mariani, M., Casaioli, C., Accadia, M., Llasat, M. C., Pasi, F., Davolio, S., Elementi, M., Ficca, G., and Romero, R.: A limited area model intercomparison on the "Montserrat-2000" flashflood event using statistical and deterministic methods, Nat. Hazards Earth Syst. Sci., 565-581, 2005.

Milelli, M., Llasat, M. C., and Ducrocq, V.: The cases of June 2000, November 2002 and September 2002 as examples of Mediterranean floods, Nat. Hazards Earth Syst. Sci., 6, 271-284, 2006, http://www.nat-hazards-earth-syst-sci.net/6/271/2006/.

Rigo, T. and Llasat, M. C.: A methodology for the classification of convective structures using meteorological radar: application to heavy rainfall events on the Mediterranean Coast of the Iberian Peninsula, Nat. Hazards Earth Syst. Sci., 4, 59-68, 2004, http://www.nat-hazards-earth-syst-sci.net/4/59/2004/. 